\title{
Prevalence of needle stick injury and its associated factors among nurses working in public hospitals of Dessie town, Northeast Ethiopia, 2016
}

\author{
Awoke Kebede* and Hadgu Gerensea
}

\begin{abstract}
Objective: Nurses are exposed to dangerous and deadly blood borne pathogens through contaminated needle stick injuries. This study was designed to assess prevalence of needle stick injury and its associated factors among nurses working in hospitals. Institution-based cross-sectional study design was used among 258 randomly selected nurses. Collected data was entered into Epi-Data version 3.1 and transferred to SPSS Version 20.0 for analysis. The degree of variables were assessed using adjusted odds ratio and its $95 \%$ confidence interval with $P$ value $(<0.05)$.
\end{abstract}

Results: Eighty-nine (34.5\%) nurses self-reported receiving a needle stick injury in the previous 12 months. Work experience, working hour, personal protective, infection prevention guide line utilization and infection prevention training were significantly associated to needle stick injury.

Conclusions: The needle stick injury in this study area was prevalent. The contributing factors to the injury were duration of working hours, experience, use of personal protective equipment and training.

Keywords: Prevalence, Associated factors, Needle stick injury, Nurse

\section{Introduction}

The National Institute for Occupational Safety and Health (NIOSH) USA defines a needle stick injury as injuries that are caused by objects such as hypodermic needles, blood collection needles, cannula and needles used to connect parts of IV delivery systems. Health Professionals who are exposed to needles in their clinical activities are at high risk of acquiring a needle stick which may lead to a serious or fatal infection with blood borne pathogens such as hepatitis B virus (HBV), hepatitis C virus (HCV) or human immunodeficiency virus (HIV) [1, 2].

Approximately 3 million HCWs are exposed to blood borne viruses each year. Blood has been implicated as the source of the exposure in nearly all occupationally

\footnotetext{
*Correspondence: honeyfikir1@gmail.com
}

School of Nursing, College of Health Sciences and Referral Hospital,

AKsum University, Axum, Ethiopia acquired infections. Exposures occur through needle sticks contaminated with an infected patient's blood or through contact of the eye, nose or mouth with the patient's blood [3-5]. On average, a healthcare worker (HCWs) in Africa suffers two to four needle stick injuries per year $[6,7]$.

NSI is one of the greatest risks faced by the front line health care worker. Yet, these exposures have often been considered as part of the job $[8,9]$. Nurses are an integral part of clinical services and have primary responsibility for a greater proportion of patient care in most health care settings [10]. Nurses are at high risk to occupational hazards and injuries in the course of their day to day activities in the health care environment [11]. By considering the nature of the nurses' working environment, responsibilities and duties, nurses are at high risk of numerous occupational hazards such as infectious disease, chemical risks, environmental risks, and psychosocial risks [12-15]. 
A few studies reported high prevalence of needle stick injury in central and eastern part of the country [16]. Therefore this study aims to assess the prevalence and associated factors among nurses working in public hospitals of Dessie town, Northeast Ethiopia.

\section{Main text \\ Methodology \\ Study area and period}

The study was conducted at public hospitals of Dessie town, Dessie, which is located at $401 \mathrm{~km}$ Northeast of Addis Ababa. The health facilities which are found in Dessie are two governmental hospitals, eight health centers, two NGOs clinics, three private hospitals 27 different size private clinics. The study was conducted from November 2015 to June, 2016.

\section{Study design}

Institutional based cross-sectional study design was conducted.

\section{Sample size}

A total of 313 samples were calculated using a single population proportion formula by assuming $5 \%$ marginal error and 95\% confidence interval $(\sigma=0.05)$ and Prevalence of the needle stick injury $18.7 \%$ [17] and by adding $10 \%$ of non-response rate.

\section{Sampling technique and procedures}

About 258 subjects were selected using simple random sampling technique. The sample size had been distributed into each hospital according to proportional to population allocation. To select individual participant from each hospital, lottery method was used.

\section{Data collection tools and techniques}

Data was collected by using structured self-administered questionnaire adapted from previous similar literatures. Two days training was given to all data collectors and supervisors prior to pretesting. Eight data collectors who had completed diploma in nurses were recruited.

\section{Data processing and analysis}

The collected data was coded, cleaned and entered into Epi-Data version 3.1 and transferred to Statistical Package for Social Sciences (SPSS) version 20.0 for analysis. $\mathrm{Bi}$-variable and multivariate logistic regression model were done to identify the relative importance of each predictor to the dependent variable by controlling for the effect of other variables. Those variables which were potential independent predictors on Bivariable analysis with $\mathrm{P}$-value $<0.25$ was entered to multivariable logistic regression analysis.

\section{Ethical considerations}

The Ethical approval was approved by the Institutional Review Board (IRB) of College of Health Sciences, Aksum University. Communications with the health center administrations was made through a formal letter obtained from Aksum University, College of Heath Science and TRHB. The objective and importance of the study was explained to the study participants. Data was collected after full informed written consent was obtained from participants aged 18 years and more, but age less than 18 years from the guardian.

\section{Results}

\section{Socio-demographic Characteristics}

Two hundred fifty eight nurses were included in this study. The response rate was $97.6 \%(\mathrm{n}=252)$. The majority of the respondents 141 (56\%) were females. More than two-thirds $[171(67.9 \%)]$ of the respondents reported being between the age of 20-29 years. One hundred and sixty eight (66.7\%) respondents reported 168 (66.7\%) having less than or equal to 5 years work experience. Additionally, 152 (60.3\%) of participants had a degree and above. Two hundred one (79.8\%) of the nurses work less than or equals to $40 \mathrm{~h}$ per week (See Table 1 ).

\section{Prevalence and circumstances of needle stick injury}

The prevalence of needle stick injury among nurses working in public hospitals of Dessie town was $34.5 \%(n=87)$ and $48.8 \%(n=123)$ for the last year and throughout their career, respectively. From the total of respondents who had ever experienced needle stick injury, 84 (68.3\%) were exposed to NSI only once. Hallow bore needle 71 (57.7\%) followed by Suturing needle 35 (28.5\%) was the most common devices involved in the injuries. Among

Table 1 Socio-demographic characteristics of nurses working in public hospitals of Dessie Town, March, 2016 ( $n=252)$

\begin{tabular}{llll}
\hline Variables & Description & Frequency & Percent (\%) \\
\hline Sex & Male & 111 & 44 \\
Age group & Female & 141 & 56 \\
& 20-29 years & 171 & 67.9 \\
& 30-39 years & 35 & 13.9 \\
Experience & 40-49 years & 46 & 18.2 \\
& 55 years & 168 & 66.7 \\
Educational status & 5-10 yeas & 31 & 12.3 \\
& $>10$ years & 53 & 21.0 \\
Working hours per week & Diploma & 100 & 39.7 \\
& Degree and above & 152 & 60.3 \\
& $>40 \mathrm{~h}$ & 201 & 79.8 \\
\end{tabular}


injured nurses, $53.7 \%$ of the injuries occurred during night shift. The highest risky areas was surgical ward which accounts 26 (21.1\%). One hundred three (82.7\%) of accidents occurred in a noisy, dimly lit working environment. Regarding the degree of the injury, 69 (56.1\%) respondents reported that the injury they were suffered was superficial. More than two-third 86 (66.9\%) of injured nurses didn't receive post exposure prophylaxis. Similarly, the majority of nurses 208 (82.5\%) used personal protective equipment during a procedure while 123 (59.4\%) reported using single glove as their personal protective equipment. Two hundred forty $(95.2 \%)$ of nurses disposed of the needle using a safety box after completion of the procedures. only 177 (70.2) of nurses had knowledge of an infection prevention guideline and only three-quarters $(n=190)$ followed the guidelines. More than two-thirds $(\mathrm{n}=177)$ and an almost equal number $(n=185)$ of nurses had received the hepatitis $B$ vaccine and training on infection prevention respectively (See Table 2).

Procedures played a role in the causes needle stick injury, injection is the leading one (24.4\%) followed by suturing $(16.3 \%)$.

\section{Factors associated to needle stick injury}

Based on a multiple logistic regression result, nurses with work experience greater than 10 years were more than six times at higher risk to sustain needle stick injury than those who work experience were less than or equals to 5 years with $(\mathrm{AOR}=6.321,95 \% \mathrm{CI} 2.865-13.948)$. Nurses who worked greater than $40 \mathrm{~h}$ per were nearly three times at higher risk to sustain needle stick injury than those who worked hours less than or equals to $40 \mathrm{~h}$ per week with (AOR $=2.903,95 \%$ CI 1.297-6.498). Nurses who do not use personal protective equipment during procedure were five times at more risk to sustain needle stick injury than their counter parts (AOR $=5.055$, 95\% CI 2.01512.688). The risk of needle stick injury was nearly five times higher in nurses who didn't follow infection prevention guidelines than those followed it $(\mathrm{AOR}=4.623$, 95\% CI 2.052-10.416). Nurses who didn't receive infection prevention training were nearly six times at more risk than nurses who received training $(\mathrm{AOR}=5.780$, 95\% CI 2.691-12.415) (See Table 3).

\section{Discussion}

Needle stick injuries are the most common route by which blood-borne viruses and/or infections such as HIV and hepatitis B and C. Such infections serve as high occupational risks and threats to healthcare workers, especially where basic rules of occupational safety and health are not implemented [18]. Among nurses who are working in public hospitals of Dessie town, the prevalence of needle stick injury in the previous 12 months prior to the survey was $34.5 \%$. This finding is in line with results from previous study of Jigjiga (32.7\%) and Hawassa (35.8\%), Ethiopia [19, 20].

But this finding is higher than findings of Australia and Malaysia which is 17.7 and $27.9 \%$ respectively [21, 22] and lower than findings of Korea (70.4\%) and Iran (54\%) $[23,24]$. Current result is also lower than studies of Addis Ababa and Jimma, Ethiopia (51.6 and 39.3\%) respectively $[25,26]$. The possible reason for difference in the proportion of injury could be the socio-demographic/economic status and cultural differences in self-reporting behavior. It also could be due to the difference in the study health facility setups, implementation of universal precaution, mixing up of study participants (all types of health care personnel Vs nurses only) and even the year of the study.

With regard to experience, the odds of sustaining needle stick injury was higher for nurses with work experience greater than 10 years than those whose work experience is less than or equals to 5 years with. This is in line with report from Portugal and Pakistan indicating experience greater than 10 years increases risk for sustaining needle stick injury and those with experience greater than 5 years are at greater risk to sustain NSI respectively $[27,28]$. This could be explained by more exposure due to longer duration of services and hence more NSI among more experienced nurses as compare to those working for greater than 5 years. Younger workers apply more recently acquired knowledge into practice, while experienced familiarity may contribute to taking fewer precautions and paying less attention at work, which are likely to increase the chance of human error and contribute to risk behaviors.

Regarding to working hours per week, nurses whose working hour per week greater than $40 \mathrm{~h}$ were nearly three times at higher risk to sustain needle stick injury compared to those whose working hours per week is less than or equals to $40 \mathrm{~h}$. This is similar with the finding of Iran and Sub-Saharan Africa [24, 29]. This is also in agreement with result from Jigjiga, eastern Ethiopia [19]. This could be explained by work load makes health professionals to be stressed, loss their ability to concentrate and fatigue, which are more likely to increase the chance of human error and contribute to a tendency towards risky behaviors and poor compliance with the precautions in general. It also suggests the problem of under-staffing in developing countries. Hence it has implications for policy makers and hospital administrators to ensure that working hours do not exceed than those prescribed in legislation.

Nurses who do not use personal protective equipment during procedure were more than four times at more risk to sustain needle stick injury than their 
Table 2 Prevalence and circumstances of needle stick injury among nurses working in public hospitals of Dessie Town, March, $2016(n=252)$

\begin{tabular}{|c|c|c|c|}
\hline Variables & Description & Frequency & Percent (\%) \\
\hline \multirow[t]{2}{*}{ NSI } & Yes & 123 & 48.5 \\
\hline & No & 129 & 50.5 \\
\hline \multirow[t]{2}{*}{ Duration } & Within 1 year & 87 & 34.5 \\
\hline & Before a year & 36 & 14.3 \\
\hline \multirow[t]{4}{*}{ How often } & Once & 84 & 68.3 \\
\hline & Two to four times & 29 & 23.6 \\
\hline & $\geq$ five times & 7 & 5.7 \\
\hline & Didn't recall & 3 & 2.4 \\
\hline \multirow[t]{3}{*}{ Materials leading to injury } & Hallow bore needle & 71 & 57.7 \\
\hline & Suturing needle & 35 & 28.5 \\
\hline & Cannula & 18 & 13.8 \\
\hline \multirow[t]{2}{*}{ Working shift } & Day & 57 & 46.3 \\
\hline & Night & 66 & 53.7 \\
\hline \multirow[t]{8}{*}{ Working area/unit } & OPD & 10 & 8.1 \\
\hline & Emergency & 19 & 15.4 \\
\hline & Pediatric ward & 21 & 17.1 \\
\hline & Medical & 19 & 15.4 \\
\hline & Surgical & 26 & 21.1 \\
\hline & OR & 15 & 12.2 \\
\hline & OBY-GYNI & 7 & 5.7 \\
\hline & ICU & 6 & 4.9 \\
\hline \multirow[t]{4}{*}{ Condition of working environment } & Bright light & 16 & 13.0 \\
\hline & Dim light & 47 & 38.2 \\
\hline & Noisy & 56 & 45.5 \\
\hline & Room temperature & 4 & 3.3 \\
\hline \multirow[t]{3}{*}{ Injury type } & Superficial & 69 & 56.1 \\
\hline & Moderate & 50 & 40.6 \\
\hline & Deep & 4 & 3.3 \\
\hline \multirow[t]{2}{*}{ Did you get Rx after injury? } & Yes & 37 & 30.1 \\
\hline & No & 86 & 69.9 \\
\hline \multirow[t]{2}{*}{ Did you use PPE? } & Yes & 208 & 82.5 \\
\hline & No & 44 & 17.5 \\
\hline \multirow[t]{4}{*}{ Type of PPE used } & Single glove & 123 & 59.4 \\
\hline & Double glove & 73 & 35.3 \\
\hline & Mask & 9 & 4.3 \\
\hline & Goggle & 2 & 1.0 \\
\hline \multirow[t]{2}{*}{ Did you safety box? } & Yes & 240 & 95.2 \\
\hline & No & 12 & 4.8 \\
\hline \multirow[t]{2}{*}{ Did your hospital has IP guideline? } & Yes & 177 & 70.2 \\
\hline & No & 75 & 29.8 \\
\hline \multirow[t]{2}{*}{ Did you follow IP guide line? } & Yes & 190 & 75.4 \\
\hline & No & 62 & 24.6 \\
\hline \multirow[t]{2}{*}{ Did you received HBV Vaccine? } & Yes & 177 & 70.2 \\
\hline & No & 75 & 29.8 \\
\hline \multirow[t]{2}{*}{ Did you received HBV IP training? } & Yes & 185 & 73.4 \\
\hline & No & 67 & 26.6 \\
\hline
\end{tabular}


Table 3 Factors Associated with Occurrence of Needle Stick Injuries among Nurses Working in Public Hospitals of Dessie Town, March, 2016 ( $n=252)$

\begin{tabular}{llll}
\hline Variables & $\begin{array}{l}\text { Injury } \\
\text { status }\end{array}$ & COR With $95 \% \mathrm{Cl}$ & AOR With $95 \% \mathrm{Cl}$ \\
\cline { 2 - 2 } & Yes No & \\
& &
\end{tabular}

\begin{tabular}{|c|c|c|c|c|}
\hline \multicolumn{4}{|l|}{ Age group } & \multirow[t]{4}{*}{-} \\
\hline 20-29 years & 71 & 100 & 1.00 & \\
\hline 30-39 years & 22 & 13 & $2.38(1.126-5.046)^{*}$ & \\
\hline $40+$ years & 30 & 16 & $2.641(1.340-5.206)^{*}$ & \\
\hline \multicolumn{5}{|c|}{ Experience category } \\
\hline$\leq 5$ years & 73 & 95 & 1.00 & 1.000 \\
\hline $5-10$ years & 15 & 16 & $1.220(0.566-5.046)^{*}$ & $2.331(0.925-5.871)^{* *}$ \\
\hline$>10$ years & 35 & 18 & $2.530(1.1327-4.842)^{*}$ & $6.321(2.865-13.948)^{* *}$ \\
\hline \multicolumn{5}{|c|}{ Working hours per week } \\
\hline$\leq 40 \mathrm{~h}$ & 87 & 114 & 1.00 & 1.000 \\
\hline$>40 \mathrm{~h}$ & 36 & 15 & $3.15(1.619-6.108)^{*}$ & $2.903(1.297-6.498)^{* *}$ \\
\hline \multicolumn{5}{|l|}{ Use of PPE } \\
\hline Yes & 87 & 121 & 1.00 & 1.000 \\
\hline No & 36 & 8 & $6.26(2.773-14.127)^{*}$ & $5.055(2.015-12.688)^{* *}$ \\
\hline \multicolumn{4}{|c|}{ Use of safety box } & - \\
\hline Yes & 113 & 127 & 1.00 & \\
\hline No & 10 & 2 & $5.62(1.206-26.191)^{*}$ & \\
\hline \multicolumn{4}{|c|}{ Availability of guide line } & - \\
\hline Yes & 65 & 112 & 1.00 & \\
\hline No & 58 & 17 & $5.88(3.156-10.939)^{*}$ & \\
\hline \multicolumn{5}{|c|}{ Follow IP guide line } \\
\hline Yes & 73 & 117 & 1.00 & 1.000 \\
\hline No & 50 & 12 & $6.68(3.334-13.375)^{*}$ & $4.623(2.052-10.416)^{* *}$ \\
\hline \multicolumn{5}{|c|}{ Receiving IP training } \\
\hline Yes & 71 & 114 & 1.00 & 1.000 \\
\hline No & 52 & 15 & $5.56(2.916-10.623)^{*}$ & $5.780(2.691-12.415)^{* *}$ \\
\hline
\end{tabular}

* Significantly associated at COR

** Significantly associated at AOR

counter parts. This is in line with previous report from Hawassa, south Ethiopia and other, which was $86.4 \%$ of HCWs use PEP consistently and those who don't use were significantly associated accidental needle stick injury $[5,20]$. This can also be explained by those who follow universal precaution are believed to have a good knowledge, and attitude and applied to prevent injury.

Those nurses who had not attended any training on prevention and management of needle stick injuries in their workplace were at a significantly greater risk of sustaining such injury compared with those who had attended some kind of training. This finding is similar with reports of Sub-Saharan Africa and Kenya $[29,30]$. This also in line with finding in Jimma, south west Ethiopia [26]. This may be explained by effective training enhances awareness and improves skills of nurses to reduce unsafe behaviors and implementing organizational strategies to prevent exposure to reduce the risk of such injuries.

\section{Conclusions}

This study revealed that more than one-third of the study participants had needle stick injury at least once in the previous 12 months. Inadequate occupational health and safety measures were factors associated with needle stick injury. So that ministry of health and heath professionals associations should create awareness on health professionals on safety measures.

\section{Limitation}

By considering nurses are prone for needle stick injury we focuses on those health professionals but all health professionals are at risk and further study is need and systemic review is mandatory to made generalization. Furthermore, the study does not show cause and effect relationship.

\section{Abbreviations}

Cl: confidence interval; AOR: Adjusted Odd Ratio; SPSS: Statistical Package for Social Sciences; NSI: needle stick injury among nurses working in public hospitals of Dessie town.

\section{Authors' contributions}

AK: conceived and designed the study, analyzed the data and wrote the manuscript. HG involved in data analysis, drafting of the manuscript and advising the whole research paper. $\mathrm{HG}$ also were involved in the interpretation of the data and contributed to manuscript preparation. All authors read and approved the final manuscript.

\section{Acknowledgements}

We would like to thank all study participants and data collectors for their contribution in success of our work.

\section{Competing interests}

This manuscript maintains no competing financial interest declaration from any person or organization, or non-financial competing interests such as political, personal, religious, ideological, academic, intellectual, commercial or any other.

Availability of data and materials

The data sets used and analyzed during the current study available from the corresponding author on reasonable request.

\section{Consent to publish \\ Not applicable.}

\section{Ethics approval and consent to participate}

Ethical clearance was secured from the Aksum University, College of Health Science research review committee. An official letter of permission was obtained from Tigray Regional Health Bureau. Respondents were well informed about the purpose of the study, and information was collected after full oral and written consent from participants. Information was recorded anonymously and confidentially, and beneficence was assured throughout the study period.

\section{Funding}

There is no funding for this research. All cost of data collection and analysis were covered by the authors. 


\section{Publisher's Note}

Springer Nature remains neutral with regard to jurisdictional claims in published maps and institutional affiliations.

Received: 16 March 2018 Accepted: 22 June 2018

Published online: 28 June 2018

\section{References}

1. Norsayani MY, Noor HI. Study on incidence of needle stick injury and factors associated with this problem among medical students. J Occup Health. 2003;45(3):172-8.

2. Kermode M, Jolley D, Langkham B, Tomas MS, Crofts N. Occupational exposure to blood and risk of blood borne virus infection among health care workers in rural north Indian health care settings. Am J Infect Control. 2005:33(4):34-41.

3. Shiao J, Guo L, Laws ML. Estimation of the risk of blood borne pathogens to health-care workers after a needle stick injury in Taiwan. Am J Infect Control. 2005;30(1):15-20.

4. Glenngård AH, Persson U. Costs associated with sharps injuries in the Swedish health care setting and potential cost savings from needlestick prevention devices with needle and syringe. Scand J Infect Dis. 2009:41(4):296-302

5. Prüss-Ustün E. Rapiti and Y. Hutin. Estimation of the global burden of disease attributable to contaminated sharps injuries among health-care workers. Am J Ind Med. 2005;48(6):482-90

6. Elmiyeh B, Whitaker IS, James MJ, et al. Needle-stick injuries in the National Health Service: a culture of silence. J R Soc Med. 2004:97(7):326-7.

7. Jovic-Vranes A, Jankovic S, Vranes B. Safety practice and professional exposure to blood and blood-containing materials in Serbian health care workers. J Occup Health. 2006;48(5):377-82.

8. Sagoe MC, Pearson RD, Perry J, Jagger J. Risks to health care workers in developing countries. N Engl J Med. 2010;345(7):538-41.

9. Foley M, Leyden TA, American Nurses Association's. Needle stick prevention guide. Washington, D.C: American Nurses Association's; 2002. p. 1-25.

10. Ramsay JA. The development and use of JHAs in the emergency department. J Saf Health Environ Res. 2005:2(2):2-18.

11. Isara AR, Ofili AN. Prevalence of occupational accidents/Injuries among health care workers in a federal medical center in southern Nigeria. West Afr J Med. 2012;31(1):47-51.

12. Senthil A, Anandh B, Jayachandran P, et al. Perception and prevalence of work-related health hazards among health care workers in public health facilities in southern India. Int J Occup Med Environ Health. 2015;21(1):74-81.

13. Carayon P, Gurses AP. Nursing workload and patient safety-A human factors engineering perspective. An evidence-based handbook for nurses. Agency Healthcare Res Qual. 2005;21(5):284-301.

14. Environment American Nurses Association Healthy Work. Health and Safety Survey. 2006;106(9):104.
15. Smith $D$, Leggat P. Needle stick and sharps injuries among nursing students. J Adv Nurs. 2005;51(5):449-55.

16. Tadesse M, Tadesse T. Epidemiology of needle stick injuries among health-care workers in Hawassa City, Southern Ethiopia. Trop Doct. 2010:40(2):111-3.

17. Lulie W, Emebet A, Mesihanit T, Hana F, Dereje B, Muluken A. Factors Associated with needle stick and sharp injuries, among health care workers in Felege Hiwot Referral Hospital, Bahir Dar, Northwest Ethiopia: facility based cross-sectional survey. Int J Infect Control. 2013:9(4):1-9.

18. Sagoe MC, Pearson RD, Perry J, Jagger J. Risks to health care workers in developing countries. N Engl J Med. 2011;345(7):538-41.

19. Mideksa L, Feyera T. Needle-Stick Injuries and Contributing Factors among Health care Workers in Public Health Facilities in Jigjiga Zone, Eastern Ethiopia. World J Med Sci. 2014;11(4):490-6.

20. Beyene H, Yirsaw BD. Occupational risk factors associated with needlestick injury among healthcare workers in Hawassa City, Southern Ethiopia. Occup Med Health Aff. 2014;6(2):1-5.

21. Smith DR, Smyth W, Leggat $P$, et al. Needle stick and sharps injuries among nurses in a tropical Australian hospital. Int J Nurs Pract. 2006:12(1):71-7.

22. Rampal L, Zakaria R, Sook LW, Zain AM. Needle stick and sharps injuries and factors associated among health care workers in a Malaysian Hospital. Eur J Soc Sci. 2010;13(3):354-62.

23. Cho $\mathrm{E}$, Lee $\mathrm{H}$, Choi M, et al. Factors associated with needle stick and sharp injuries among hospital nurses. Int J Nurs Stud. 2013;50(8):1025-32.

24. Jahangiri M, Rostamabadi A, Hoboubi N, Tadayon N, Soleimani A. Needle stick injuries and their related safety measures among nurses in a university hospital, Shiraz, Iran. Saf Health Work 2016;7(1):72-7.

25. Desalegn Z, Gebreselassie S, Asemamaw Y. Epidemiology of needle stick-sharp injuries and potential high risk exposures among health professionals in Ethiopia: neglected public health concern. Am J Health Res. 2015;3(5):298-304.

26. Bidira K, Woldie M, Nemera G. Prevalence and predators of needle stick injury among nurses working in public hospitals of Jimma zone. Int J Nurs Midwifery. 2014;6(7):90-6.

27. Martinsa A, Coelhob CA, Manuela M. Age and years in practice as factors associated with needle stick and sharps injuries among health care workers in a Portuguese hospital. Accid Anal Prev. 2012:47(1):11-5.

28. Ahmed Khan E, Aziz A. Prevalence and factors associated with needle stick injuries among registered nurses in public sector tertiary care hospitals of Pakistan. Int J Collab Res Intern Med Public Health. 2011:3(2):124-30.

29. Sadoh WE, Fawole AO, Sadoh AE. Practice of universal precautions among healthcare workers. Int Med Assoc. 2006;9(2):722-6.

30. Mbaisi1 $\mathrm{M}$, et al. Prevalence and factors associated with percutaneous injuries and splash exposures among health-care workers in a provincial hospital, Kenya; 2010. http://www.panafrican-med-journal.com/content/ article/14/10/full/. Accessed 29 Dec 2015.

Ready to submit your research? Choose BMC and benefit from:

- fast, convenient online submission

- thorough peer review by experienced researchers in your field

- rapid publication on acceptance

- support for research data, including large and complex data types

- gold Open Access which fosters wider collaboration and increased citations

- maximum visibility for your research: over 100M website views per year

At $\mathrm{BMC}$, research is always in progress.

Learn more biomedcentral.com/submissions 